\title{
The effects of beetroot consumption on blood pressure, heart rate, perceived exertion and the speed of running in young female athletes
}

\author{
$\underline{\text { Mohammad Reza Kordi }}{ }^{1}$, Maryam Salimi Nahrsolduz ${ }^{2}$, Babak Hooshmand Moghadam ${ }^{3}$ \\ 1. Associate Professor, Department of Physiology and Sport Sciences, University of Tehran, Tehran, Iran (Corresponding \\ Author), Tel: 00982188351730, Email: mr.kordi@ut.ac.ir, ORCID ID: 0000-0002-6796-1696 \\ 2. Ms.c, Department of Physiology and Sports Science, University of Tehran, Tehran, Iran. ORCID ID: 0000-0002-5099- \\ 3309 \\ 3. PhD student, Department of Physiology and Sport Sciences, Ferdowsi University of Mashhad, Mashhad, Iran. ORCID ID: \\ 0000-0002-2036-9492
}

\begin{abstract}
Background and Aim: Beetroot is a rich source of antioxidants and rich in nitrates. The present study aimed to investigate the effects of beetroot consumption on blood pressure, heart rate, perceived Exertion, and the speed of running in young female athletes.

Material and Method: For this purpose, 10 young female athletes participated in this crossover double blind study. Subjects were randomly placed into placebo $(\mathrm{n}=5)$ or beetroot $(200 \mathrm{~g}$ containing $500 \mathrm{mg}$ Nitrate; $\mathrm{n}=5$ ) groups. They ran $5 \mathrm{Km}$ on treadmill. The wash-out period for them was one week. Systolic and diastolic blood pressure were measured before and 3 hours after beetroot consumption and after the 5 Kilometer run. Heart rate, perceived exertion, and the speed of running at the distances of 1.6 and 3.2 kilometers were recorded. Two-way ANOVA with repeated measures and independent t-test were used for data analysis.

Results: The results showed that beetroot consumption significantly reduced systolic blood pressure before and after the exercise, and reduced diastolic blood pressure before the exercise. Heart rate was significantly decreased in beetroot group after 1.6 and 3.2 kilometers run, but no significant difference was found between beetroot and placebo groups at the end of 5 kilometer run. Perceived exertion was significantly reduced at the end of 1.6 kilometer run but not after 3.2 and 5 kilometer run in the beetroot group. The alterations in the speed of running at 1.6, 3.2 and 5 kilometers were not significantly different between the groups.
\end{abstract}

Conclusion: According to the results of this study, in addition to the health benefits of vegetables, nitrate-rich vegetables can improve performance of training.

Keywords: Beetroot consumption, Blood pressure, Heart rate, Perceived exertion, Female athletes

Received: Dec 30, $2018 \quad$ Accepted: Jan 21, 2020

\footnotetext{
How to cite the article: Mohammad Reza Kordi, Maryam Salimi Nahrsolduz, Babak Hooshmand Moghadam. The effects of beetroot consumption on blood pressure, heart rate, perceived exertion and the speed of running in young female athletes.SJKU 2020;25(4):79-92.
}

Copyright (C) 2018 the Author (s). Published by Kurdistan University of Medical Sciences. This is an open access article distributed under the terms of the Creative Commons Attribution-Non Commercial License 4.0 (CCBYNC), where it is permissible to download, share, remix, transform, and buildup the work provided it is properly cited. The work cannot be used commercially without permission from the journal 


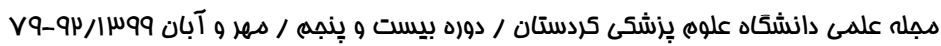

\section{تأثير مصرف جغنلدر بر فشارخون، ضربان قلب، ميزان درك فشار تمرين و سرعت دويدن دختران جوان ورزشكار

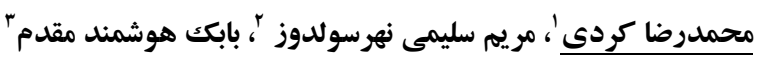

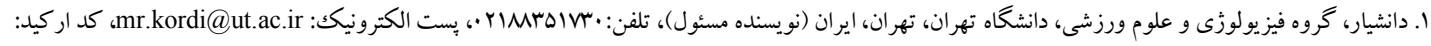 \\ ........ Y-9V99-1999

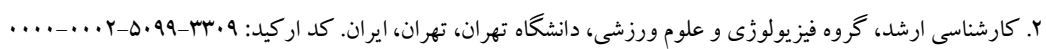

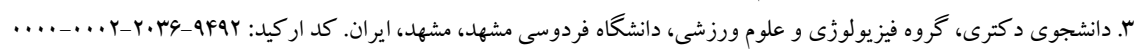

جـكيله

زمينه و هدف: جغندر منبع غنى از آنتى اكسيدانها و سرشار از نيترات است. هدف از يزّوهش حاضر، بررسى تأثير مصرف جغندر بر فشارخون، ضربان قلب، ميزان دركك فشار تمرين و سرعت دويدن دختران جوان ورزشكار بود.

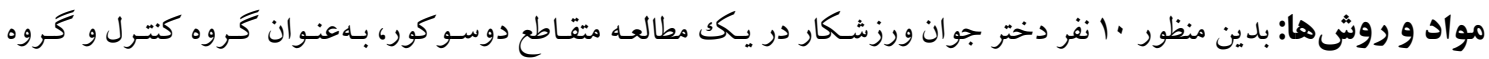
آزمايش موردمطالعه قرار گرفتند. آزمودنىهابه دو گروه يْجنفرى تقسيم شدند و در دو آزمون ينج كيلومتر دويـدن روى تردميـل،

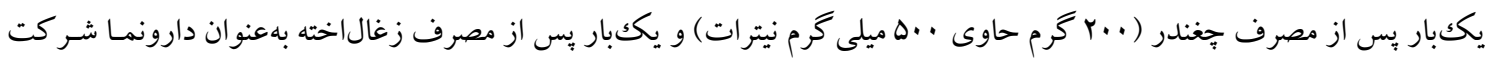
كردند. فشارخون سيستوليكك و دياستوليكك قبل از مصرف (جغندر و دارونما) و سه ساعت يس از مصرف و در پيايـان يـنج كيلـومتر

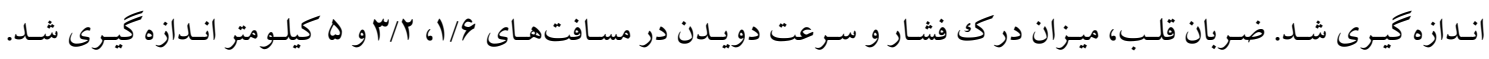
تجزيهو تحليل آمارى با استفاده از آزمون آناليز واريانس با اندازه كيرى مكرر و t مستقل و نرمافزار SPSS انجام شد. يافته ها: مصرف جغندر باعث كاهش معنى دارى در فشارخون سيسـوليك قبـل از فعاليـت و يايـان يـنج كيلـومتر و باعث كاهش

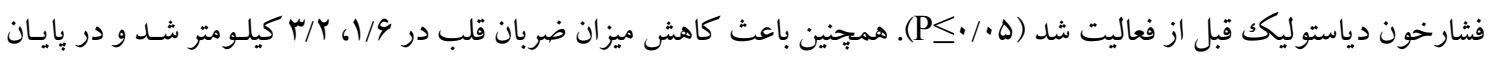
ينج كيلومتر دويدن هيج اختلاف معنىدارى بين مصرف جغنندر و دارونما مشـاهده نشـد و ميزان دركك فشـار تمـرين رادر مسـافت

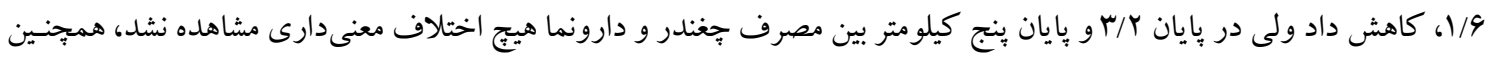

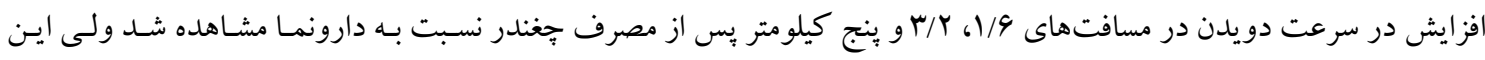

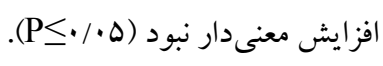
نتيجه گيرى: بر اساس يافتهاى يُزوهش حاضر، مصرف جغندر مىتوانند كارايى تمرينى رادر دختران جوان ورزشكار بهبود

كلمات كليدى: جغندر، فشارخون، ضربان قلب، ميز ان درك فشار، دختران جوان ورزشكار

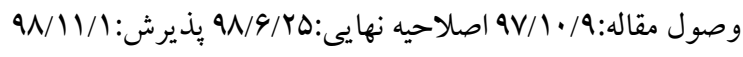


يك منبع عالى از آنتىاكسيدانها و beta vulgaris

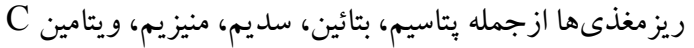
و نيترات (')

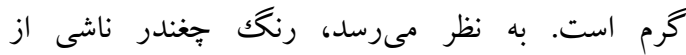

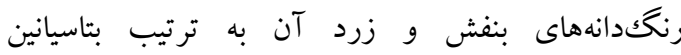
(Betacyanin) روىهمرفته بتالائين (Betalains) ناميده مىشود. اين بتالائين ها، قابليت بالقوه آنتى اكسيدانى دارند(F). بتائين يكك Amino acid ( ترى متال مشتق از آمينو اسيد كلايسين (Glycine ) است(ه) كه منجر به ترويج استقامت عضلانى، قدرت و توان مىشود(4). نيترات (NO3) جغندر توسط باكترىهاى درون حفره دهانى و بهوسيله باكترىهاى خاص لماص درون بافتها مانند اكزانتين اكسايد (Oxantin oxaid) به نيتريت كاهش بيدا مى كند. جندين مسير براى متابوليسم نيتريت (NO)

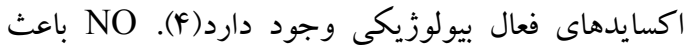

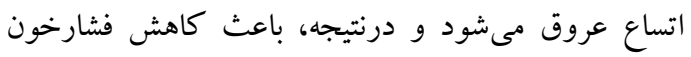

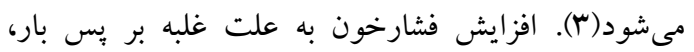
باعث محدود شدن و فلات در حجم ضربهاى مىشود؛ بنابراين قلب براى افزايش برون ده قلب، متناسب با نياز بدن به ضربان قلب متكى مىشود و ضربان قلب افزايش مى يابد. كاهش فشارخون با افزايش حجم ضربهاى اجازه مىدهد كه برون ده قلبى اتكاى خود به حجم ضربهاى را حفظ كند و ضربان ثابت بماند يا كاهش يابد(VO). NO بهعنوان يكك عامل شل كننده اندوتليال شناختهشده است، درنتيجه از يرفشار خونى جلو گيرى مى كند. NO همجنين بهعنوان يك

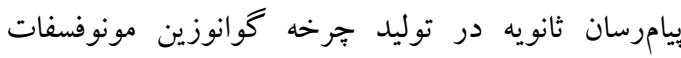
هم عمل مى كند و در (Guanosine monophosphat) اتساع عضلات صاف هم درگير است(^). شكلى از نيترات مواد غذايى از فعاليت اكسيداسيون سيتوكروم جلو گيرى

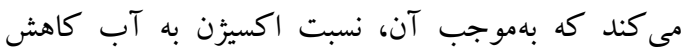
مى يابد. NO خاصيت فسفوريلاسيون اكسيداتيو و همجنين
يكى از عوامل اساسى و بسيار مؤثر كه در عملكردهاى

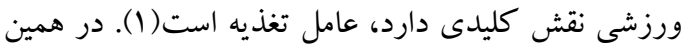
راستا، يُزوهشهاى انجاميافته در حوزه علم تغذيه ورزشى، لهي، دامنه بسيار گستردهاى از اطلاعات علمى رادر اختيار جامعه ورزشى قرار مىدهد و ازاينرو در برنامهريزىهاى مختلف ورزشى از اهميت و جايخاه ويزهاى برخوردار است(ب، ()). از آنجايى كه يكى از اهداف اصلى ورزشكاران بهبود ميزان عملكرد است، ورزشكاران و مربيان در ردههاى مختلف، درصدد دستيبى به عواملى هستند كه عملكردشان را روزبهروز ارتقا دهند؛ بنابراين، علاوه بر برنامههاى تمرينى، در حوزه علم تغذيه، هر عاملى كه بتواند علاوه بر تأمين انرزى، عملكرد را به نحو مطلوب بهبود بخشد، حائز اهميت است(r-1). آكاهى مربيان و ورزشكاران از اهميت علم تغذيه، ساختار و تركيبات مختلف مواد غذايى و متابوليسم آنها، از عوامل موفقيت و كسب ركوردهاى بهتر است(f) (F). در اين ميان، همانند ساير علوم كه با كسب

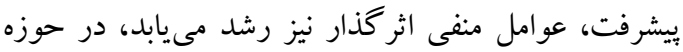
علم تغذيه نيز استفاده از داروها و محرككها و مواد نيروزا عرصهاى گسترده فراهم آورده است و افرادى را كه بدون داشتن آكاهى از خطرات فردى و اجتماعى ناشى از مصرف

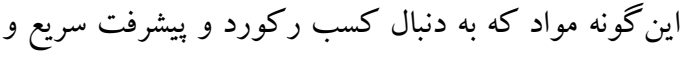

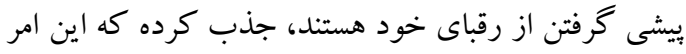
رسالت يزوهشخران و مربيان علوم ورزشى را در راستاى ترى

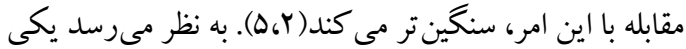

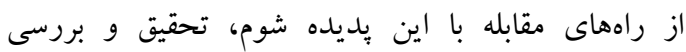

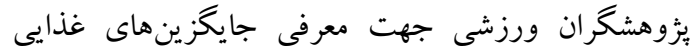
مناسب و معرفى مكملهاى سالم و سودمند غذايى لمانى است( (9). از جمله مكملهاى غذايى مناسب مىتوان به مكمل هايى كه داراى نيترات (NO) هستند، اشاره كرد. نيترات مواد غذايى مئوتواند بهوسيله

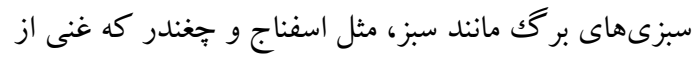

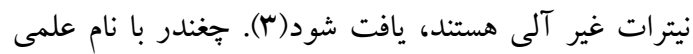


عاملى براى افزايش جذب نيترات، اثرات ارگگزّنيكى دارد يا خير؟ ازآنجاكه در داخل كشور تحقيقى در مورد تأثير مصرف جغندر بر عملكرد ورزشى به عمل نيامده و فقط تعلداد اندكى تحقيق در خارج از كشور انجامشده است و به دليل نتايج متفاوتى كه از تحقيقات بهدست آمده و همجنين به دليل اندكك بودن تحقيق روى هغندر تام، انجام اين تحقيق ضرورى به نظر مىرسد؛ بنابر اين هدف از اين مطالعه تأثير مصرف جغندر بر فشارخون، ضربان قلب، ميزان دركى فشار تمرين و سرعت دويدن دختران جوان ورزشكار بودهه

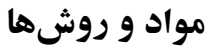

يثزوهش حاضر از نوع مداخلهاى متقاطع است. جامعه آمارى

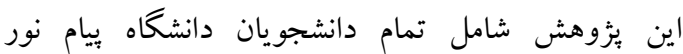
مشكين شهر با دامنه سنى Yr TV TV ساله بودند. بعد از تكميل بر سشنامه تندرستى و فعاليت بدنى، از بين افراد واجد شرايط و داوطلب ·1 نفر بهعنوان نمونه انتخاب شدند. در اين

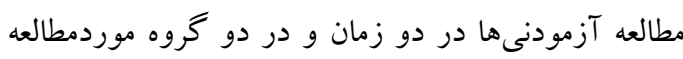

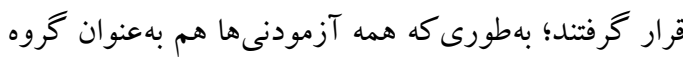

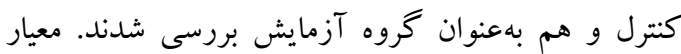

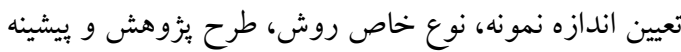

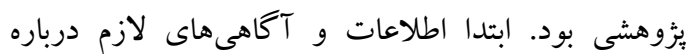

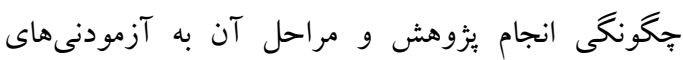

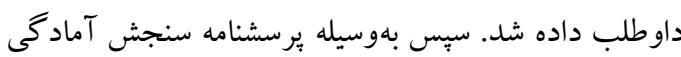
براى فعاليت بدنى (PAR-Q)(19) اطلاعاتى درباره ميزان

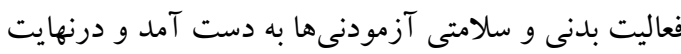
فرم رضايتنامه شر كت در آزمون به آزمودنىها ارائه شد. بهعلاوه به آزمودنىهاى داوطلب توصيه شد تا از مصرف

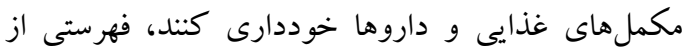
غذاهاى ير نيترات در اختيار آزمودنىهاى داوطلب قرار

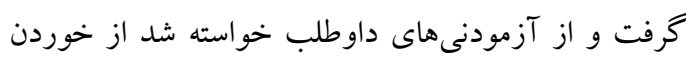
غذاهاى ير نيترات Vr ساعت قبل از آزمون اجتناب كنند. همجنين از آنها خواسته شد تا از خوردن كافئين و استفاده
نسبت فسفات به اكسيزن بهويزه اين نسبت را در ميتو كندرى مدئ

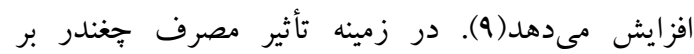

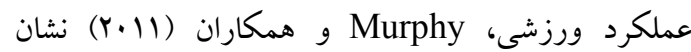
دادند، سرعت دويدن در بايان بنج كيلومتر دويدن بعد از

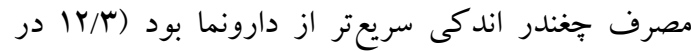

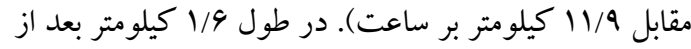
مصرف جغندر نسبت به دارونما سرعت دويدن پينج درصد

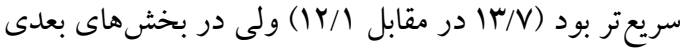
اختلافى بين مصرف جغندر و دارونما مشاهده نشد. ميزان دركك فشار در كل ينج كيلومتر هيج اختلافى با دارونما را نشان نداد، فقط در طول 1/9 كيلومتر ميزان دركك فشار بس از مصرف جغندر نسبت به دارونما كاهش داشت و نشان دادند، هيج اختلاف معنىدارى در فشارخون و ضربان قلب

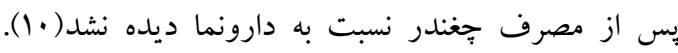
و و همكاران (1ansley ليتر آب جغندر زمان اتمام جهار كيلومتر دويدن، كاهش و قدرت خروجى افزايش مىيابد(11). Bailey و همكاران

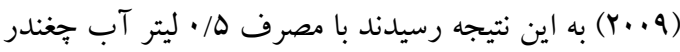

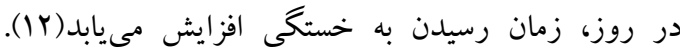
lansley مصرف ..0ه ميلىليتر آب خغندر به مدت شش روز باعث كاهش فشارخون و هزينه اكسيرن طى راه رفتن و دويدن

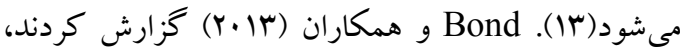

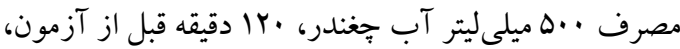
NO پِلاسما را افزايش، اكسيزّن مصرفى، فشارخون

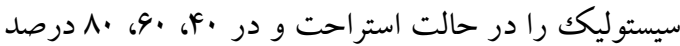
حداكثر اكسيزن مصرفى كاهش و هيج تأثير معنىدارى بر فشارخون دياستوليك، ضربان قلب، برون ده قلبى نشان نداد(1). باينحال، شواهد علمى نشان داده است، آب جغندر موجب كاهش زمان اتمام فعاليت(1)، •(1)، افزايش

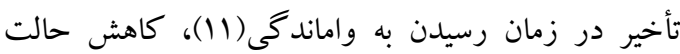
بايدار اكسيرن برداشتى، افزايش توان اوج و همجينين

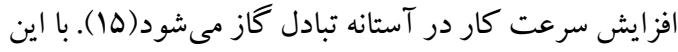
حال هنوز مشخص نيست، آيا مصرف جغندر تام، بهعنوان 
فشارخون دوباره در حالت خوابيده اندازهگيرى شد. در جلسه بعد جاى آزمودنىها تغيير كرد و به گروه پنج نفر اول زغالاخته و به گروه ينج نفر دوم جغندر داده شد و همان شرايط جلسه اول اعمال و از آزمودنى ها خواسته شد با همان سرعتى كه در جلسه اول شروع به دويدن كرده بودند در جلسه دوم هم با همان سرعت كار خود را آغاز كنند (زمان اندازه گيرى متغيرها در جدول شماره ا قابل مشاهده است). نحوه درست كردن مكمل در اين يثوهش اين گونه بود كه جغندر به مدت ·ه دقيقه در اجاقهاى تجارى يخته و به

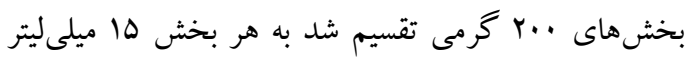
آبليمو و دو ميلىليتر جوزهندى و دارجين براى طعم دار

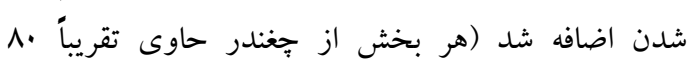

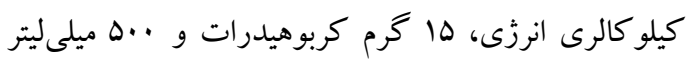
نيترات بود). دارونما در اين يثوهش زغالاخته بود كه

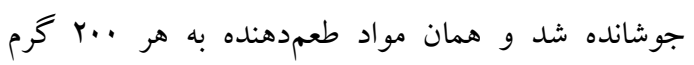
دارونما اضافه شد. هشت گرم شكر به زغال اخته اضافه شد تا ميز ان كالرىاش با جغندر يكسان شود (هر بخش از دارونما

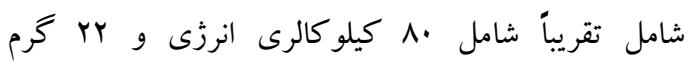
كربو هيدرات و فاقد نيترات بود)( •(1).

در اين يزٔوهش قد آزمودنىها با استفاده از متر نوارى با دقت / / • سانتىمتر اندازهيرى شد. آزمودنىها با بر تن داشتن حداقل لباس براى جند ثانيه و بدون حركت روى روى ترازوى Beurer مدل PS05 ساخت كشور آلمان ايستادند

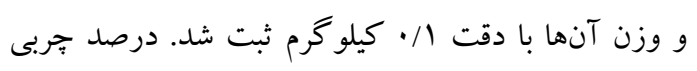
زيريوستى با استفاده از كاليير Lafayette مدل 01127A

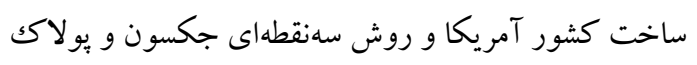
در نواحى يشت بازو، شكم و ران سمت راست بدن

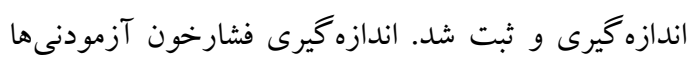

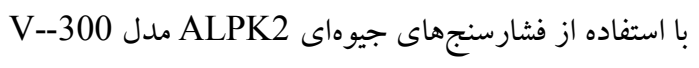
EU فشارخون سيستولى بر اساس اولين صداى كوروتكوف و

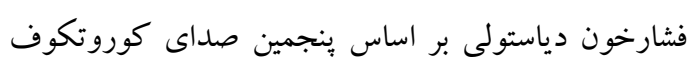

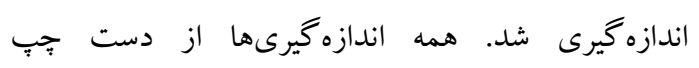
آزمودنىها و در وضعيتى كه دست آنها موازى با سطح
از دهانشويه YF ساعت قبل از آزمون و از انجام تمرينهاى قدرتى Vr ساعت قبل از آزمون خوددارى كنند. هر · آ آزمودنى يس از شركت در جلسه آشنايى با شرايط و محيط كار در دو جلسه آزمون بنج كيلومتر دويدن به فاصله

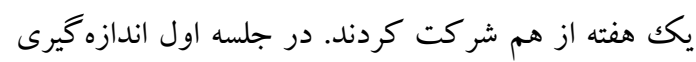
شاخص قد، وزن و تر كيب بدنى از آزمودنى ها به عمل آمد. توالى رويدادها در طول آزمون بدين شكل بود: آزمودنىها در ساعت هشت صبح در آزمايشگاه حضور داشتند. آزمودنىها به دو گروه ينجنفرى تقسيم شدند. در جلسه اول

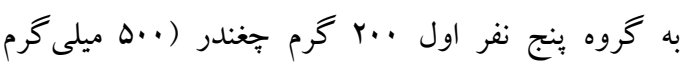
نيترات) و به گروه ينج نفر دوم زغالاخته داده شد. قبل از مصرف جغندر يا دارونما فشارخون در حالت خوابيده از آزمودنىها به عمل آمد. در طول ها دقيقه از آزمودنىها خواسته شد كه تمام جغندر يا دارونما را مصرف كنند بعد از سه ساعت از شروع مصرف جغندر يا دارونما دوباره فشارخون از آزمودنىها كرفته شد، آزمودنىها بس از ينج دقيقه انجام حركات كششى و كرم كردن، روى تردميل رفته و كار خود را با سرعت دلخواه كه مىتوانستند با همان سرعت تا يايان ينج كيلومتر به كار خود ادامه دهند، شروع به دويدن كردند. براى به حداقل رساندن تداخل، در طول به به به ينج كيلومتر دويدن فشارخون اندازه گيرى نشد. ضربان قلب

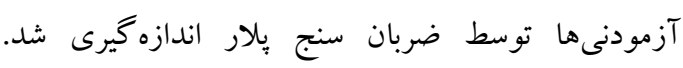
حداكثر ضربان قلب هم با توجه به فرمول (سن - ·. Tr) به دست آمد تا از آن براى محاسبه ضربان قلب در حين ورزش بهعنوان درصدى از حداكثر ضربان قلب استفاده شود و ميزان دركك فشار، توسط شاخص 4 تا.بr امتيازى بورگك سنجيده شد. ضربان قلب و دركك فشار در كيلومتر و ب/ ب كيلومتر و در يايان ينج كيلومتر دويدن سنجش شد. همجنين سرعت دويدن بر اساس زمانهاى

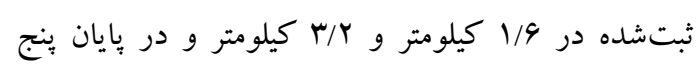
كيلومتر سنجيده شد. آزمودنىها اجازه داشتند با هر سرعتى ليك متره كه مىخواستند بدوند و فقط سرعت اوليه كه كارشان را با آن شروع مى كردند ثبت شد تا در جلسه بعد با همان سرعت كار خود را آغاز كنند. يس از اتمام آزمون بلافاصله 


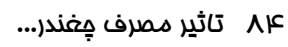

استنباطى براى مقايسه گرووهها باهم استفاده شد. ابتدا طبيعى بودن توزيع دادهها با استفاده از آزمون كولموكروف اسميرنف (K-S) تعيين شد. با توجه به نرمال بودن دادهها،

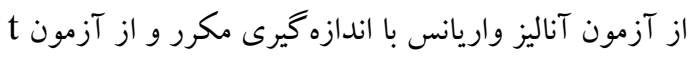
مستقل براى بررسى تغييرات درون گروهى و بين گروهى و در صورت معنى دار بودن از آزمون تعقيبى بانفرونى استفاده شد. سطح معنىدارى آمارى نيز (هـ/• شد. براى رسم نمودارها از نرمافزار 2010 Excel و براى آناليز دادهها از نرمافزار SPSS نسخه Y Y استفاده شد.
قلبشان قرار داشت، گرفته شد. بهمنظور اندازه كيرى ضربان قلب، از دستگًاه ضربان سنج Beurer مدل PM80؛ ساخت كشور آلمان استفاده شد. در اين ئزوهش براى اجراى

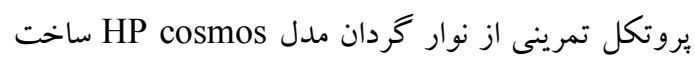
كشور آلمان استفاده شد. تحليل آمارى براى تجزيهو تحليل دادههاى اين بثروهش از روشهاى آمار توصيفى و استنباطى استفاده شد. از آمار توصيفى براى محاسبه ميانكين و انحراف استاندارد دادهها و از آمار

جدول ا. زمان اندازه كيرى متغيرها

\begin{tabular}{|c|c|c|c|}
\hline سرعت دويدن & ميزان درك فشار & ضربان قلب & فشارخون \\
\hline يس از 19/اكيلومتر & يس از9/اكيلومتر & يس از 9/4اكيلومتر & قبل از مصرف \\
\hline ֶِ از Y/ب كيلومتر & يֶ از ب/r كيلومتر & پِ از r/r كيلومتر & r ساعت پِ از مصرف \\
\hline يس از اتمام ه كيلومتر دو & پِ از اتمام ه كيلومتر دويدن & پِ از اتمام ه كيلومتر دويدن & پِ از اتمام ه كيلومتر دويدن \\
\hline
\end{tabular}

يافتهها جدول Y شاخصهاى آنترويومتريكى آزمودنىها را در شروع يروتكل نشان مىدهد. جدول r. شاخصهاى آنترويومتريكى آزمودنىها

\begin{tabular}{|c|c|}
\hline $\mathbf{M} \pm \mathbf{S D}$ & متغير \\
\hline$r r / F \cdot \pm r / \Delta q$ & سن (سال) \\
\hline $19 \mu / 1 \pm \Lambda / 94$ & قد (سانتى متر) \\
\hline$\Delta \Lambda / Y \cdot \pm Q / \Delta \varphi$ & وزن (كيلوكرم) \\
\hline$r \Delta / r \cdot \pm r / 9 \Delta$ & درصد جربى \\
\hline$Y \backslash / Q Y \pm Y / Y I$ & شاخص توده بدنى \\
\hline
\end{tabular}

بهعبارتديخر صرفنظر از فاصله اندازهگيرى بين گروههاى موردنظر در يثوهش، تفاوت معنىدارى وجود دارد؛ اما اثرات گروه بر درك فشار معنىدار نيست (P=/MYI)؛ بهعبارتديخر صرفنظر از فاصله اندازهيرى، بين
نتايج آناليز واريانس با اندازهگيرى مكرر مربوط به متغيرها

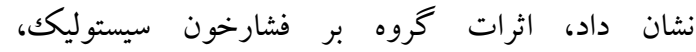
دياستوليك، ضربان قلب و سرعت دويدن معنىدار است (به ترتيب ه 
اين اختلاف در مرحله بيشآزمون (يس از مكمل سازى)

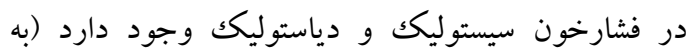

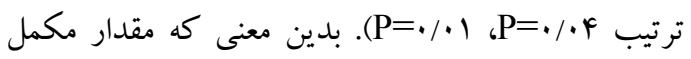
مصرفشده توسط گروه تحت بررسى تأثير معنىدارى بر ميزان فشارخون سيستوليك و دياستوليك داشته است. همجنين مقايسه مقادير فشارخون سيستوليكك بعد از فعاليت

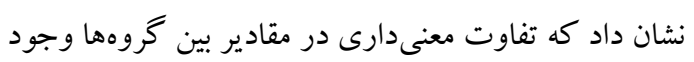

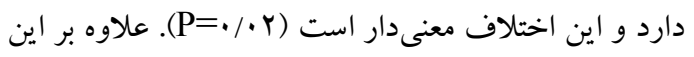

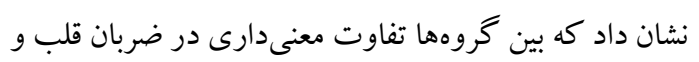

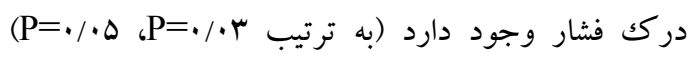

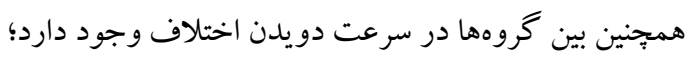

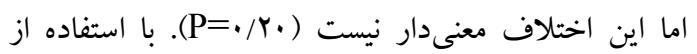
آزمون تى مستقل مشخص شد كه اين اختلاف بين خروهها

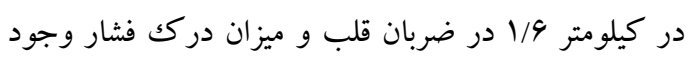

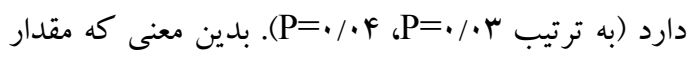
مكمل مصرفشده توسط گروه تحت بروسى تأثير معنى دارى بر ضربان قلب، درك فشار داشته است. همبِنين

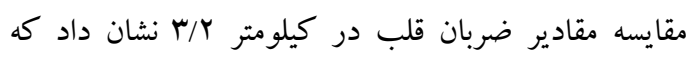

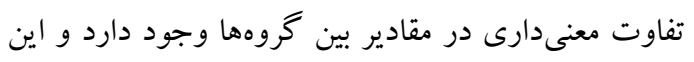

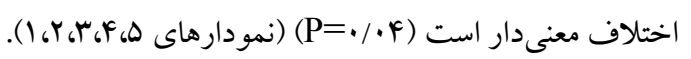

كروههاى موردنظر در پيزوهش تفاوت معنىدارى وجود ندارد. از طرفى اثر فاصله نيز بر فشارخون سيستوليك، دوردون

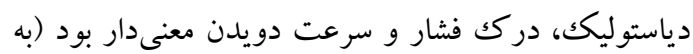

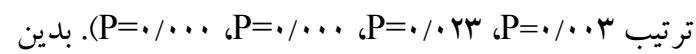
معنى كه صرفنظر از عامل گروه، اين متغيرها تحت تأثير

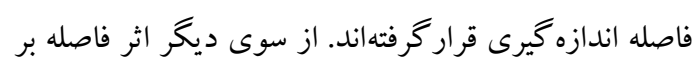

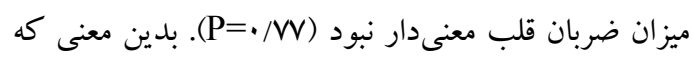
صرفنظر از عامل گروه ميزان ضربان قلب تحت تأثير

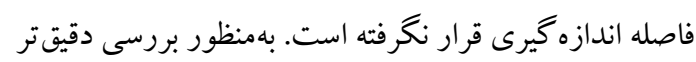
اثر تعامل گروه × فاصله نيز ارزيابى شد. نتايج آناليز

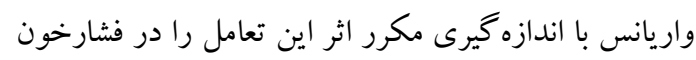

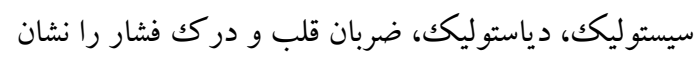

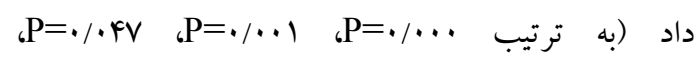

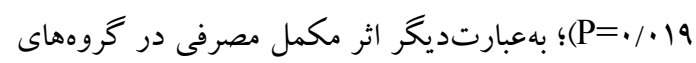
موردنظر مىتواند وابسته به فاصله باشد؛ اما نتايج آناليز

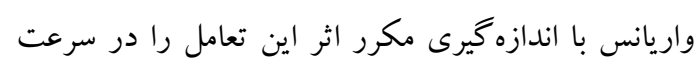

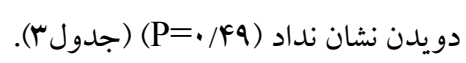

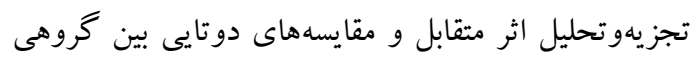
نشان داد كه بين گروهها تفاوت معنىدارى در فشارخون

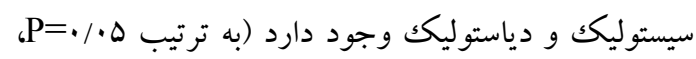

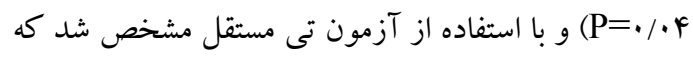


جدول r. نتايج آزمون تحليل واريانس با اندازه كيرى مكرر متغيرهاى يزوهش

\begin{tabular}{|c|c|c|c|c|c|c|}
\hline معنى سطح & مقدار F & ميانكين مربعات & آزادى درجه & مجموع مربعات & درون كروهى مقايسه & \\
\hline.$/ \cdots \Delta$ & سחس/• & $q / Q F V$ & 1 & $Q / Q F V$ & كروه & \multirow{3}{*}{ فيستوليكون } \\
\hline$\cdot \cdot r$ & G/NTr & $\Delta / \Delta 1$. & $r$ & $11 / .19$ & فاصله & \\
\hline$\% \cdots$ & $I V / V \Delta \Lambda$ & IF/MFY & r & rN/9NR & اثر متقابل & \\
\hline$\cdot / \cdot M V$ & $\Delta / \cdot V q$ & $\Delta / \mu K$. & 1 & $\Delta / \mu F$. & كروه & \multirow{3}{*}{ فشارخون } \\
\hline . & F/YYY & $r / . \Delta q$ & r & $F / l l V$ & فاصله & \\
\hline$\cdot / \cdots 1$ & $9 / 1 \cdot V$ & $F / F F I$ & r & $\Lambda / M I$ & اثر متقابل & \\
\hline . & $\Delta / \mu K$. & $v r \Delta / \ldots$ & 1 & $v r \Delta / \ldots$ & كروه & \multirow{3}{*}{ ضربان } \\
\hline$\cdot / \cdot \mathrm{WV}$ & r/VOI & $r \Delta Q / Y I V$ & r & DIN/KRT & فاصله & \\
\hline.$/ \cdot F V$ & - /MS & $\Delta r / \& \Delta$. & r & $199 / 9 \ldots$ & اثر متقابل & \\
\hline$\cdot / \mu F I$ &.$/ 909$ & $9 / 9 \ldots$ & 1 & $9 / 9 \ldots$ & كروه & \multirow{3}{*}{ در كى فشار } \\
\hline$\% \cdots$ & raY/QGT & MYI/VIV & r & STr/ATH & فاصله & \\
\hline.$/ \cdot 19$ & $F / F I V$ & $F / \wedge \Delta$. & r & $9 / v \cdots$ & اثر متقابل & \\
\hline.$/ \cdot F r$ & f/vav & YMI/DF. & 1 & MTI/DF. & كروه & \multirow{3}{*}{ سرعت } \\
\hline$\% \cdots$ & $r q r / \cdot r \Delta$ & rard/r.q & $r$ & VAV/GIr & فاصله & \\
\hline$\cdot / 49 \Delta$ & $\cdot / \mathrm{V} 19$ & $V / 19 Y$ & $r$ & $\mid F / \Gamma \wedge \Delta$ & اثر متقابل & \\
\hline
\end{tabular}




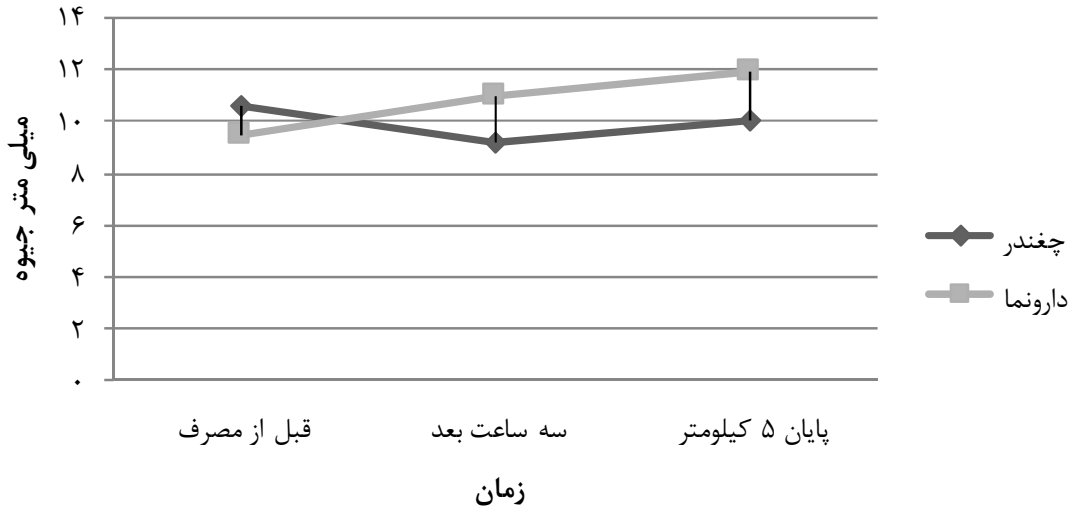

نمودار ا. مقايسه فشارخون سيستوليك يين مصرف جغندر و دارونما

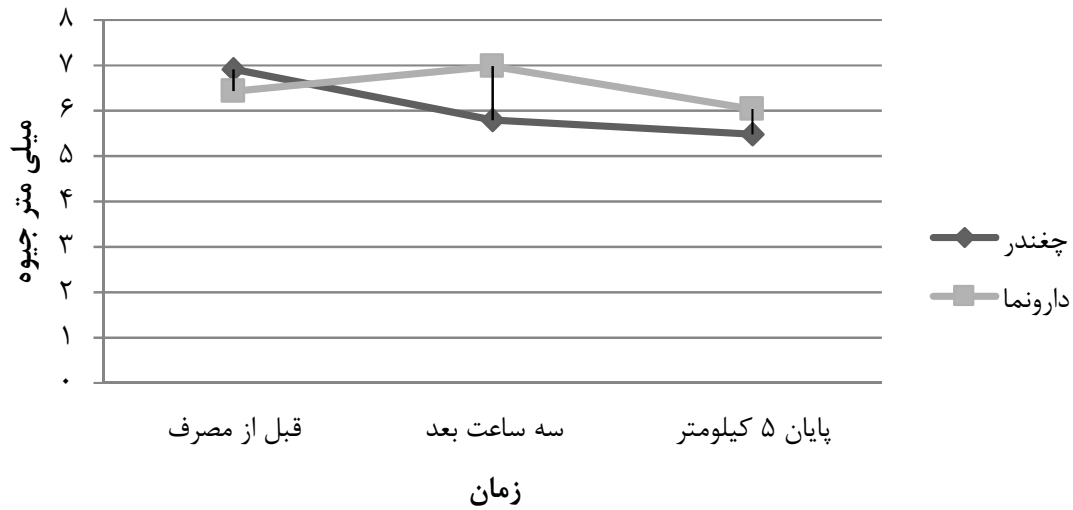

نمودار r. مقايسه فشارخون دياستوليك بين مصرف جغندر و دارونما

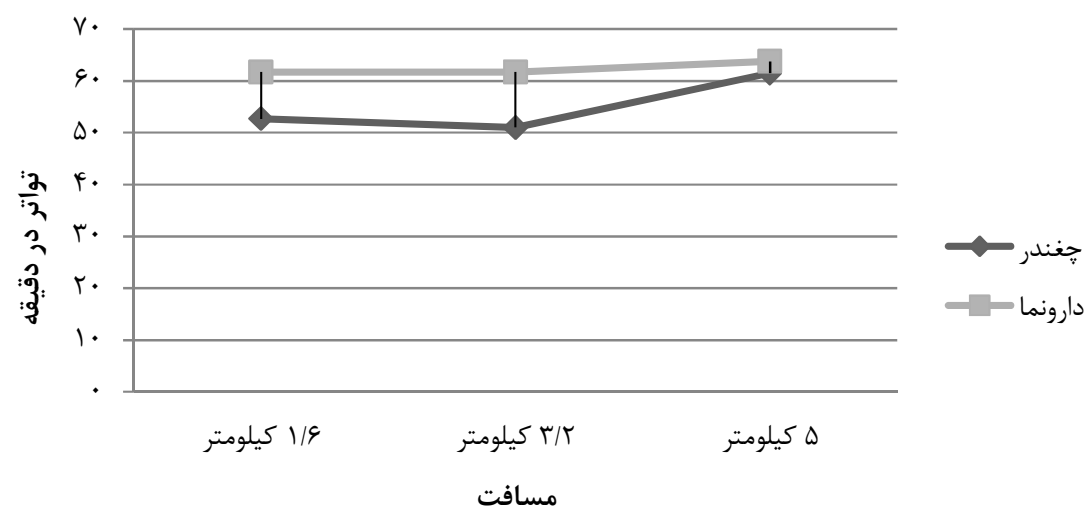

نمودار ا. مقايسه ضربان قلب بين مصرف جغندر و دارونما 


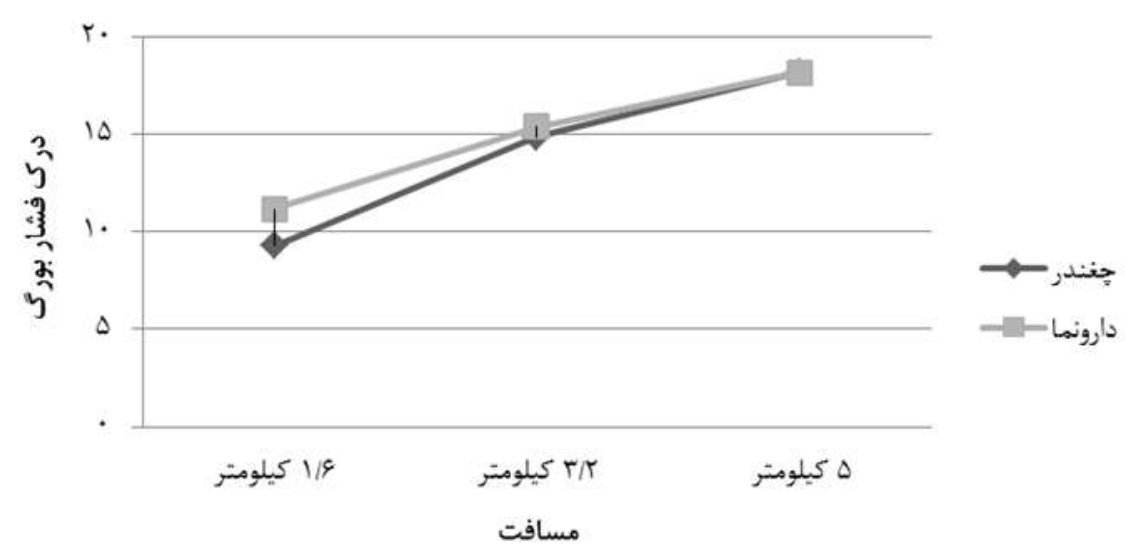

نمودار †. مقايسه ميز ان درك فثار بين مصرف جغندر و دارونما

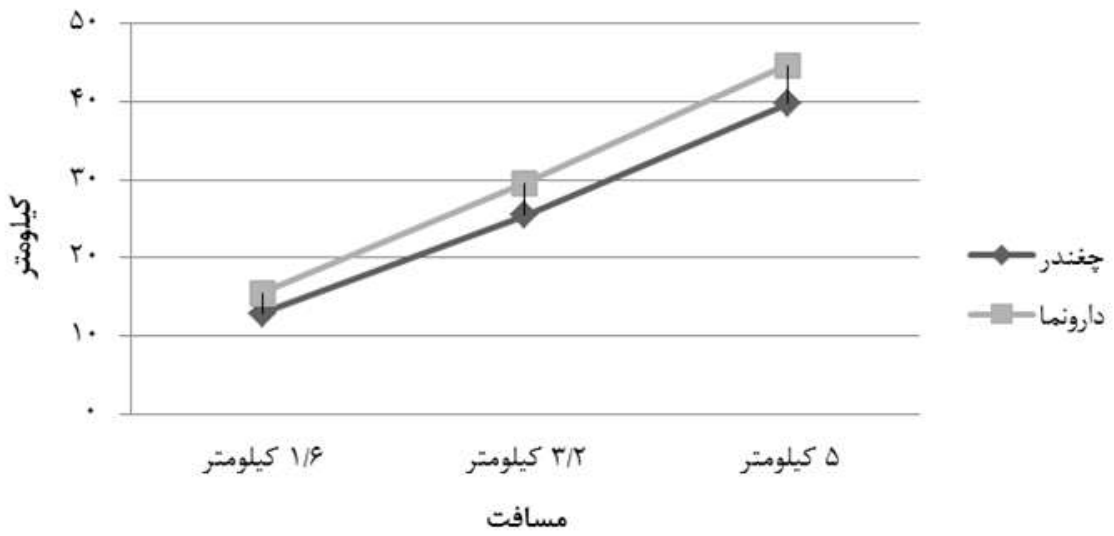

نمودار ه. مقايسه ميز ان سرعت دويدن بين مصرف جغندر و دارونما

و Vanhatalo و همكاران (IV)(Y.II) Lansley

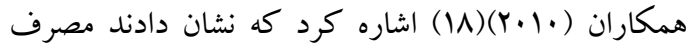
جغندر باعث كاهش فشارخون سيستوليك مى شود. دليل همسو بودن تحقيق حاضر با تحقيق باند و همكارانش،

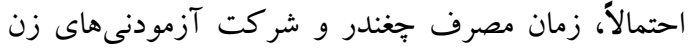

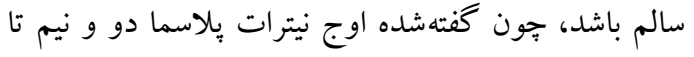

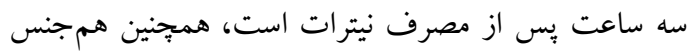

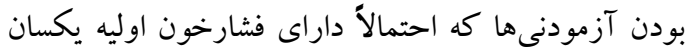
مىباشند، دليل تأثير يكسان مصرف خغندر بر ميزان فشارخون آزمودنىها است(IF) Satyanand و همكاران

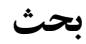

فشارخون سيستوليك: تجزيهو تحليل فشارخون سيستوليك

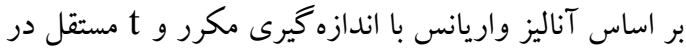

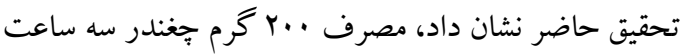

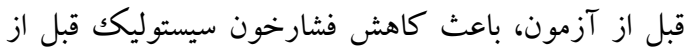
فعاليت و بايان بنج كيلومتر دويدن مىشود. همجنين مقايسه فشارخون بين گروه مصرف خغندر و دارونما نيز تفاوت معنى دارى را نشان مىدهد. همسو با يزوهش حاضر مىتوان به مطالعه Bond و همكاران (Y) Satyanand و (Y) (Y) (Y)

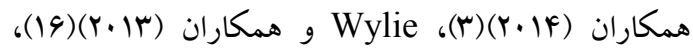




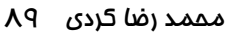

مصرف جغندر نام برد. جِون گفتهشه اوج نيترات پِلاسما دو ونيم الى سه ساعت يس از مصرف مشاهدهشده است. از

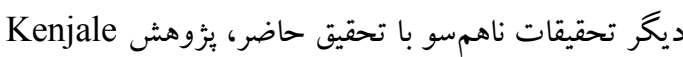

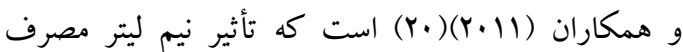
جغندر را بر روى بيماران شريان محيطى موردبررسى قراردادند و به اين نتيجه رسيدند كه مصرف آب جغندر هيج تأثيرى بر فشارخون سيستوليكك ندارد و علت آنها تغيير نيافنن اندوتليال عروقى يس از مصرف آب جغندر بيان داشتهاند و علت ناهمسويى را مىتوان بيمار بودن آزمودنىها در مطالعه كنجل اشاره كرد جون در بيماران شريان محيطى احتمالاً اندوتليال عروقى سالم نباشد درنتيجه مسير نيتريكك اكسايد سنتاز هم دجّار اختلال شده باشد و توليد نيتريك اكسايد توليدشده از اين مسير هم كم شده

فشارخون دياستوليك: تجزيهو تحليل فشارخون دياستوليك

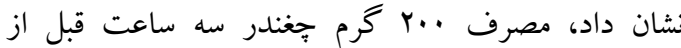
آزمون، باعث كاهش فشارخون دياستوليك قبل از فعاليت مىشود ولى بر فشارخون دياستوليك در يايان ينج كيلومتر تأثيرى نداشته است. همجنين مقايسه فشارخون بين گروه مصرف جغندر و دارونما نيز تفاوت معنىدارى را نشان مىدهد. از تحقيقات همسو با تحقيق حاضر، مىتوان به يثزوهش Kenjale و همكاران (Yll) (Y) (Y) اشاره كرد كه تأثير نيم ليتر مصرف جغندر را بر روى بيماران شريان محيطى موردبررسى قراردادند و به اين نتيجه رسيدند كه مصرف آب جغندر تأثيرى بر كاهش فشارخون دياستوليك بعد فعاليت نمىشود و علت همسويى را مىتوان استفاده از آب جغندر بهصورت تككدوز اشاره كرد. ناهمسو با تحقيق حاضر تحقيق Satyanand و همكاران (F) (r) و و (Y) Wylie

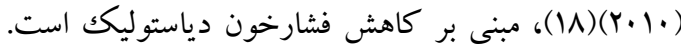
علت اين نا همسويى مىتواند متفاوت بودن مقدار مصرف جغندر و مدتزمان مصرف جغندر باشد جون در تحقيقاتى كه كاهش فشارخون دياستوليك ديده مىشود داراى ملتزمان مصرف بيشتر و مقدار مصرف بيشتر است كه اين
(Y.|F) علت اين امر را يترات موجود در جغندر مىدانند كه نيترات در بدن به نيتريك اكسايد تبديل شده و نيتريك اكسايد باعث گشادى رگكها شده و فشارخون را كاهش مىدهد(r). ميانكين فشارخون بهدست آمده در تحقيق Bond تحقيق حاضر 19.19 1.9 بوده كه اين تفاوت در فشارخونهاى بهدست آمده ممكن است به دليل متفاوت بودن سن آزمودنىها باشد جون با افزايش سن فشارخون هم افزايش مىيابد و دليل بالا بودن فشارخون در تحقيق و و همكاران (Y Satyanand آزمودنىها نسبت به تحقيق حاضر باشد و احتمالاً به دليل اختلاف آزمودنىها ازلحاظ جنسيت باشد جون ميزان فشارخون به جثه فرد، قد فرد و توليد هورمون استروزن بستگى دارد و احتمالاً به اين دلايل فشارخون در تحقيق و و همكارانش بيشتر است(r). Watyanand همكاران (r|r. (Y) علت كاهش فشارخون را به تغيير نيترات و نيتريت پِاسما نسبت دادهاند و نيتريتى كه تبديل به نيتريك اكسايد مىشود باعث اتساع شريانى شده و باعث كاهش مقاومت محيطى و درنتيجه باعث كاهش فشارخون

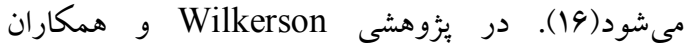

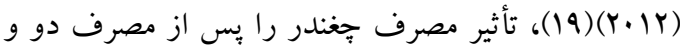
نيم ساعت قبل از آزمون بر روى مردان دوجر خهسوار ماهر موردبررسى قراردادند و به اين نتيجه دست يافتند كه فشارخون سيستوليك نسبت به گروه دارونما كاهشى نشان نداد ؛ بنابراين با نتايج اين تحقيق ناهمسو مىباشد. علت ناهمسويى را مىتوان به ماهر بودن آزمودنىها نسبت داد جون احتمال بالا بودن نيترات پيايه در افراد ماهر زياد است و همجِنين در افراد ماهر توليد نيتريكك اكسايد از مسير NOS بيشتر است. از بزوهششاى ناهمسو با اين يزوهش، تحقيق و و همكاران (11)(Yrphy .... قراردادند و گزارش كردند، مصرف جغندر تام VD دقيقه قبل از آزمون هيج تأثير معنىدارى بر روى فشارخون سيستوليك ندارد و علت ناهمسويى را مى توان احتمالاً زمان 
Go

ولى در طى ب/ ك كيلومتر و پايان پنج كيلومتر تفاوت

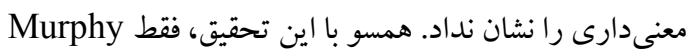

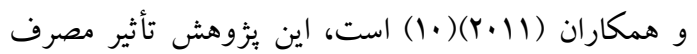
جغندر تام را بر عملكرد ورزشى موردبررسى قرار داده

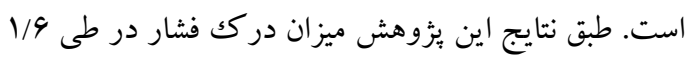

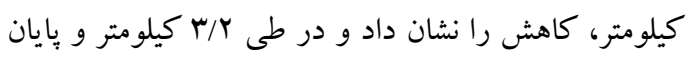

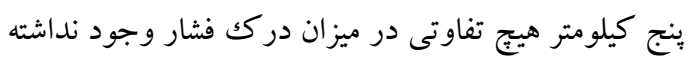

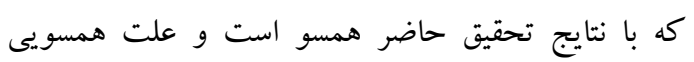
مىتواند به ضربان قلب مربوط باشد. با توجه به اينكه ميزان درك فشار با كاهش فشار فيزيولوزيكى كاهش مى ميابد،

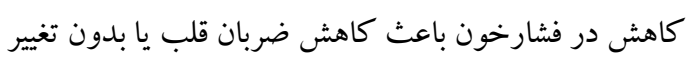

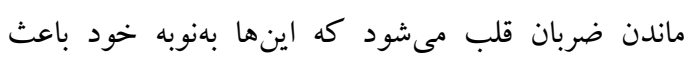
كاهش ميزان درك فشار مىشود.

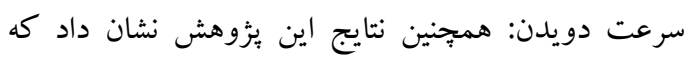

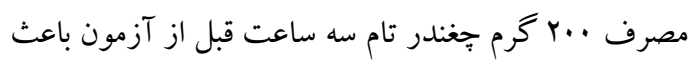

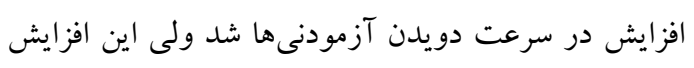

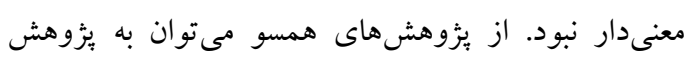
Wilkerson

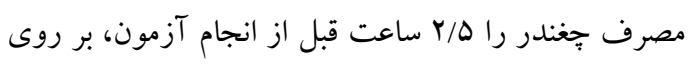
مردان دوخرخهسوار ماهر انجام داده و مشاهده كرده بودند

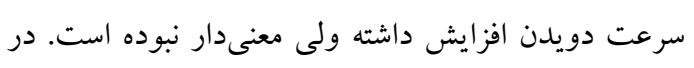

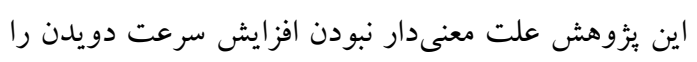
به ساز كارىهاى فيزيولوزيكى آزمودنى ها اشاره كردهاند كه

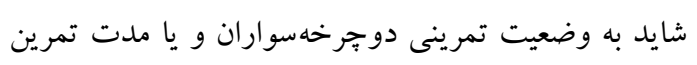

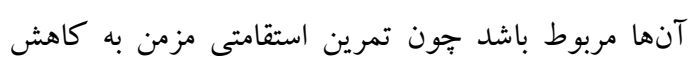
اثربخشى مكمل NO منجر مى منود. از ديخر تحقيقات

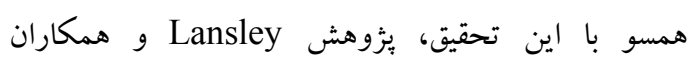

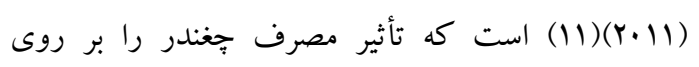

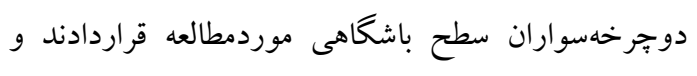
كزارش كردهاند، هم در جهار كيلومتر و هم در 19 كيلومتر

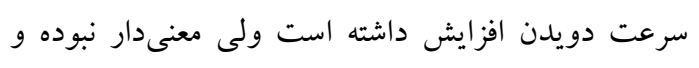
احتمال مىدهند افزايش NO عامل افزايش سرعت دويدن

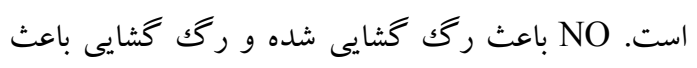
مىشود جز آهسته اكسيزن مصرفى، حداكثر اكسيزن
احتمالاً باعث بيشتر شدن نيترات هِّلاسما و درنتيجه افزايش

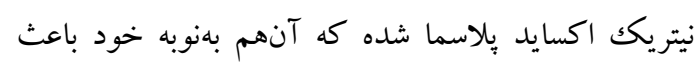

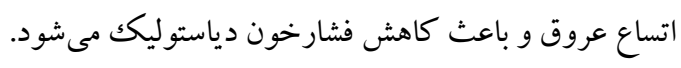

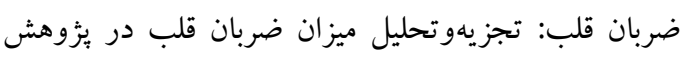

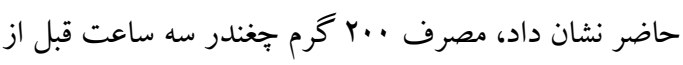

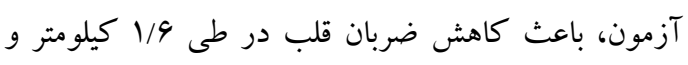

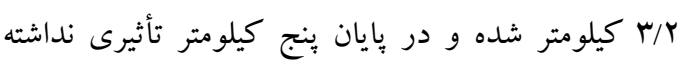

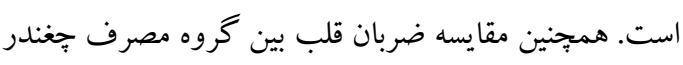

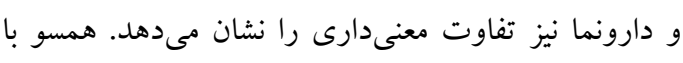
تحقيق حاضر مىتوان به تحقيق Kenjale و همكاران

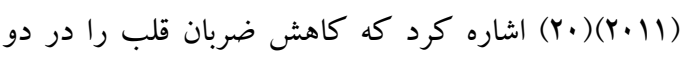
دقيقه بعد فعاليت مشاهده كرده بودند. علت همسويى را كرا مى توان احتمالاً به كاهش فشارخون در هر دو تحقيق نسبت

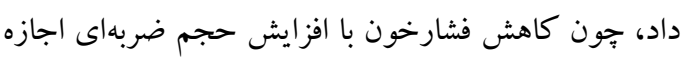

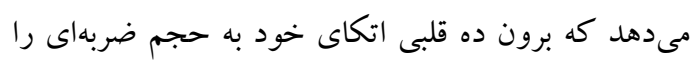

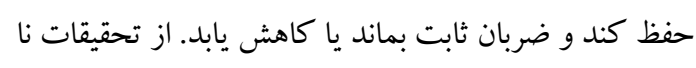
همسو با اين تحقيق، ئزوهشهاى Bond و همكاران و Cermak (Y) (Y)(Y.|Y) Murphy همه اين تحقيقات انجامشده ضربان قلب تغييرى نداشته

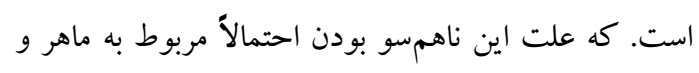

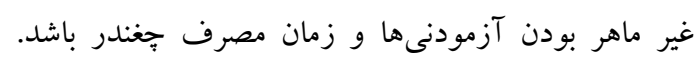

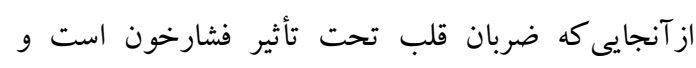

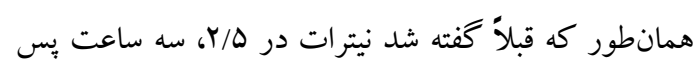
از مصرف به اوج خود مىرسد كه در غير اين صورت بر بر فئه

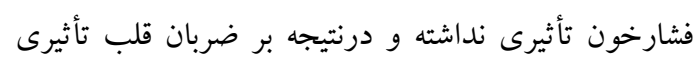

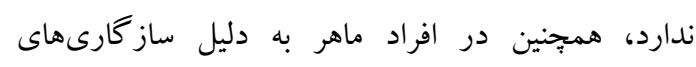

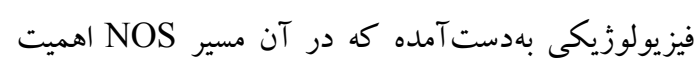

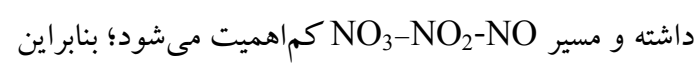
تأثير مسير

$$
\text { درنتيجه در ضربان قلب تغييرى به وجود نمى آيد. }
$$

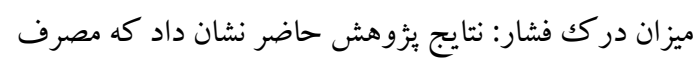
جغندر تام سه ساعت قبل از آزمون، باعث كاهش

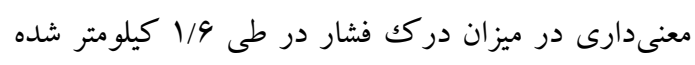


دياستوليك قبل از فعاليت (سه ساعت پس از مصرف) و

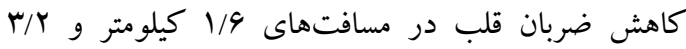

كيلومتر مىشود، اما در بنج كيلومتر تأثيرى نداشته است.

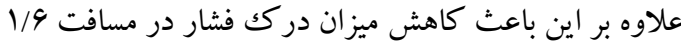

كيلومتر و باعث افزايش سرعت دويدن در مسافتهاى 1/9،

r/r و ه كيلومتر مىشود. بر اساس يافتهاى يزوهش حاضر،

علاوه بر فوايد سلامتى سبزىها، سبزىهاى غنى از نيترات

همجِين مىتواند كارايى تمرينى را نيز بهبود بخشد. اخرجها

اين يافتها بايد در ورزشكاران نخبه و ورزشهاى با زمان

هاى طولانى، مانند دو ماراتون و در ورزش هاى مختلف

ماند شنا و قايقرانى تاييد شود. همجِين مصرف خغندر

بيامدهاى آشكار براى متخصصان تغذيه در حوزه تغذيهى

ورزشكاران دارد. علاوه بر اين، زمانى كه اثرات نيروزايى

سبزىهاى غنى از نيترات و همجنين فو ايد آن بر روى افراد

با بيمارى نارسايى قلبى و افر اد سالمند ضعيف مشخص شودئ،

اين يافتها ممكن است با رزيم غذايى بالينى هم ارتباط

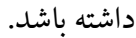

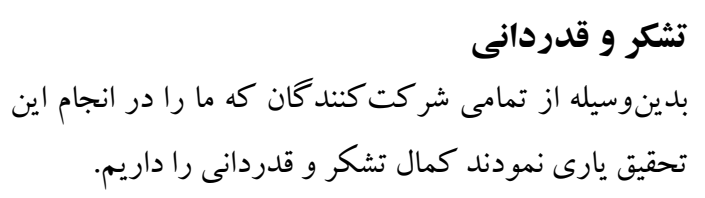

مصرفى را در طول عملكرد ورزشى بهبود بخشند كه اين بهنويه خود باعث افزايش زمان رسيدن به آستانه لاكتات

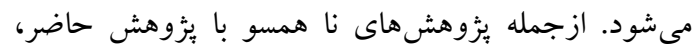

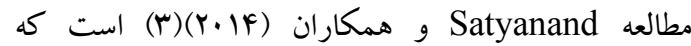
مشاهده كردند با مصرف خغندر به مدت نه هفته سرعت دويدن در آزمودنىهاى دونده مرد افزايش داشته است.

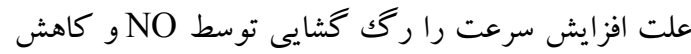

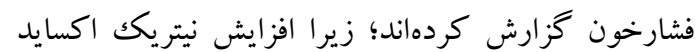
باعث كاهش فشارخون شده و تحويل اكسيزن و مواد غذايى را به عضلات فعال بهبود مىبخشد و همجنين اشارهكردهاند مكانيسمهاى فيزيولوزيكى تأثير آب خغندر بر بهر روى عملكرد ورزشى هنوز نامشخص است و علت ناهمسويى ممكن است متفاوت بودن مدتزمان مصرف جغندر باشد كه در مطالعه حاضر مطالعه بهصورت تككدوز

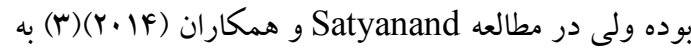

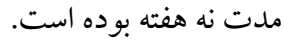

\section{نتيجه كيرى} درمجموع يافتهاى اين بثزوهش نشان مىدهد، مصرف جغندر تام قبل از آزمون باعث كاهش فشارخون سيستوليك هم قبل از فعاليت (سه ساعت پس از مصرف) و هم پس از فعاليت شده است، همجنين باعث كاهش فشارخون

1.Kerley C P, Dolan E, Cormican L. Nitrate-rich beetroot juice selectively lowers ambulatory pressures and LDL cholesterol in uncontrolled but not controlled hypertension: a pilot study. Ir J Med Sci. 2017; 8: 1-8.

2.Caldwell JT, Sutterfield SL, Frye J, Ade CJ. Beetroot Juice Enhances Functional Sympatholysis in Hypertensive Humans. The FASEB Journal. 2017; 31(1): 682-692.

3.Satyanand V, MahaboobVali S, PhaniKrishna B, Narayanasamy D, Lilly N, Mujeer, S, et al. A study of beet root derived dietary nitrate efficacy on performance of runners. IJBAMR. 2014; 3(2): 690-695. 4.Larsen FJ, Schiffer TA, Borniquel S, Sahlin K, Ekblom B, Lundberg JO, et al. Dietary inorganic nitrate improves mitochondrial efficiency in humans. Cell Metab. 2011; 13(2): 149-159.

5.Zeisel SH, Mar MH, Howe JC, Holde JM. Concentrations of choline-containing compounds and betaine in common food. J Nutr. 2003; 133:1302-1307.

6. Hoffman JR, Ratamess NA, Kang J, Rashti SL, Faigenbaum AD. Effect of betaine supplementation on power performance and fatigue. J IntSoc Sports Nutr. 2009; 27: 7-17. 
7.Jajja A, Sutyarjoko A, Lara J, Rennie K, Brandt K, Qadir O, et al. Beetroot supplementation lowers daily systolic blood pressure in older, overweight subjects. Nutr Res. 2014; 34(10): 68-75.

8.McKnight GM, Duncan CW, Leifert C, Golden MH. Dietary nitrate in man: friend or foe? BJN. 1999; 81(05): 349-358.

9.Lundberg JO, Feelisch M, Bjorne H, Jansson EA, Weitzberg E. Cardioprotective effects of vegetables: is nitrate the answer?. Nitric Oxide. 2006; 15(4): 359-362.

10.Murphy M, Eliot K, Heuertz RM, Weiss E. Whole beetroot consumption acutely improves running performance. J Acad Nutr Diet. 2012; 112(4), 548-552.

11.Lansley KE, Winyard PG, Bailey SJ, Vanhatalo A, Wilkerson DP, Blackwell JR, Jones AM. Acute dietary nitrate supplementation improves cycling time trial performance. Med Sci Sports Exerc. 2011; 43(6): 11-25.

12.Bailey SJ, Winyard P, Vanhatalo A, Blackwell JR, DiMenna FJ, Wilkerson DP, et al. Dietary nitrate supplementation reduces the $\mathrm{O} 2$ cost of low-intensity exercise and enhances tolerance to highintensity exercise in humans. J Appl Physiol. 2009; 107(4): 1144-1155.

13.Lansley KE, Winyard PG, Fulford J, Vanhatalo A, Bailey SJ, Blackwell JR, et al. Dietary nitrate supplementation reduces the $\mathrm{O}_{2}$ cost of walking and running: a placebo-controlled study. J Appl Physiol. 2010; 110(3):591-600.

14.Bond V, Curry BH, Adams RG, Asadi MS, Millis RM, Haddad GE. Effects of dietary nitrates on systemic and cerebrovascular hemodynamics. Cardiol Res Prac. 2013; 13:43-56.

15.Breese BC, McNarry MA, Marwood S, Blackwell JR, Bailey SJ, Jones AM. Beetroot juice supplementation speeds $\mathrm{O} 2$ uptake kinetics and improves exercise tolerance during severe-intensity exercise initiated from an elevated metabolic rate. Am J Physiol Regul Integr Comp Physiol. 2013; 305(12): 41-50.

16. Wylie LJ, Kelly J, Bailey SJ, Blackwell JR, Skiba PF, Winyard PG, Jones AM. Beetroot juice and exercise: pharmacodynamic and dose-response relationships. J Appl Physiol. 2013; 115(3): 325-336.

17.Lansley KE, Winyard PG, Fulford J, Vanhatalo A, Bailey SJ, Blackwell JR, Jones AM. Dietary nitrate supplementation reduces the $\mathrm{O} 2$ cost of walking and running: a placebo-controlled study. $\mathrm{J}$ Appl Physiol. 2011; 110(3): 591-600.

18.Vanhatalo A, Bailey SJ, Blackwell JR, DiMenna FJ, Pavey TG, Wilkerson DP, et al. Acute and chronic effects of dietary nitrate supplementation on blood pressure and the physiological responses to moderate-intensity and incremental exercise. Am J Physiol Regul Integr Comp Physiol. 2010; 299(4): $1121-1131$

19.Wilkerson DP, Hayward GM, Bailey SJ, Vanhatalo A, Blackwell J R, Jones AM. Influence of acute dietary nitrate supplementation on 50 mile time trial performance in well-trained cyclists. Eur J Appl Physiol. 2012; 112(12): 4127-4134.

20.Kenjale AA, Ham KL, Stabler T, Robbins JL, Johnson JL, VanBruggen M, Allen JD. Dietary nitrate supplementation enhances exercise performance in peripheral arterial disease. J Appl Physiol. 2011; 110(6): 1582-1591.

21. Cermak NM, Res P, Stinkens R, Lundberg JO, Gibala MJ, van Loon LJC. No improvement in endurance performance after a single dose of beetroot juice. Int J Sport Nutr Exercise Metab. 2012; 22(6):470-478.

22.Wilkerson DP, Hayward GM, Bailey SJ, Vanhatalo A, Blackwell JR, Jones AM. Influence of acute dietary nitrate supplementation on 50 mile time trial performance in well-trained cyclists. Eur J Appl Physiol. 2012; 112(12): 4127-4134. 